\title{
THE APLICATION OF PLAYING BASED ON REGGIO EMILIA'S APPROACH TO STIMULATE EARLY CHILDHOOD CREATIVITY
}

\author{
Novita Eka Nurjanah, Yetty Isna Wahyuseptiana \\ Universitas Sebelas Maret \\ novitapgpaud@staff.uns.ac.id
}

\section{Article History}

accepted 09/07/2018

approved 01/08/2018

published 17/09/2018

\section{Keywords}

reggio emilia's approach, childhood creativity

\begin{abstract}
The skills that must be mastered in the 21st century were creativity, critical thinking, communication, and collaboration. This was in line with Bloom's theory that creativity was the highest ability in aspects of cognitive development. Therefore important creativity was given to Early Childhood Education. Early childhood learning to stimulate creativity was done through various approaches. The approach applied didn't yet refer to the needed analysis that was in accordance with the standards of early childhood learning. The approach to stimulating the creativity of early childhood needed to be refined by referring to the stages of the child, namely learning through play. Playing must be able to stimulate the goals to be achieved. The application of playing based on reggio emilia's approach to stimulate the development of early childhood creativity. The method used was literature study by conducting a study of books and journals. The results of the analysis of theoretical studies state that playing based on reggio emillia's approach could help stimulated children's creativity after an early age. This was because the aplication of playing based on reggio emillia's approach prioritizes children's freedom in exploring the surrounding environment. This exploration activity will actively foster children's imagination. Playing based on reggio emilia's approach involves an active role in early childhood. Creativity requires space to move and playing based on the reggio emillia approach as the right link to help stimulated early childhood creativity.
\end{abstract}

Social, Humanities, and Education Studies (SHEs): Conference Series https://jurnal.uns.ac.id/shes 


\section{PENDAHULUAN}

Selama beberapa tahun terakhir, berpikir kreatif dan kreativitas telah menjadi keterampilan penting untuk beradaptasi dengan dunia yang berubah dengan cepat. Kreativitas adalah karakteristik yang dapat ditemui pada masing-masing individu sampai tingkat yang bervariasi (Runco, 1996). Torrance (1968) mendefinisikan kreativitas sebagai penerimaan terhadap masalah, gangguan dan perselisihan, menemukan kesulitan, mencari solusi, membuat dugaan, mengembangkan hipotesis mengenai masalah atau mencoba solusi baru dalam menghadapi kegagalan. Berfikir kreatif menjadi kebutuhan seseorang dalam menghadapi tantangan hidup dikarenakan akan melahirkan pola pikir yang bersifat solutif yaitu kemampuan dalam mengenali permasalahan kemudian membuat perencanaan untuk menyelesaikan permasalahan tersebut. Seseorang dalam menciptakan ide atau gagasan tentunya tidak terbentuk begitu saja. Perlu adanya stimulus yang mendorong untuk menghasilkan ide-ide, gagasan yang logis. Jika dicermati orang dewasa akan lebih mudah dalam mengasah keterampilan berfikir kreatif. Berbeda halnya dengan anak usia dini yang dalam hal ini perlu adanya pendampingan baik dari lingkungan keluarga maupun lingkungan sekolah.

Dalam sudut pandang dari para ahli, bermain adalah salah satu komponen penting kehidupan anak. Materi bermain memiliki dampak positif pada anak untuk belajar dan menjelajahi dunia dengan imajinasi yang kaya dengan cara yang menyenangkan (Celebi Oncu \& Ozbay, 2005). Imajinasi disini dapat diartikan sebagai kemampuan berfikir yang merujuk pada sejauh mana kreativitas seorang anak berkembang. Bermain merupakan faktor penting untuk kreativitas (Trevlas, Matsouka ve Zachopoulou, 2003; Russ dan Kaugars, 2001; Isenberg dan Jalongo, 1997; Russ, 1996) dan aspek kognitif kreativitas yang berhubungan dengan bermain meliputi kemampuan transformasional. dan pemikiran yang berbeda (Moore dan Russ, 2008).Penelitian juga menunjukkan bahwa anakanak yang memiliki kesempatan bermain bebas dianggap sebagai 'fantasier tinggi' dan memiliki kecenderungan lebih besar untuk berkreasi dengan materi dan situasi (Moyles, 1992). Seperti yang dicatat Baines dan Slutsky (2009), bermain cukup memperkaya kualitas hidup karena meningkatkan pemikiran kreatif. Hal ini dikarenakan bermain merupakan kegiatan yang dilakukan secara berulang-ulang dan tentunya memberikan kesempatan pada anak untuk mengembangkan ide-ide yang lebih lanjut dan tentunya sesuai dengan kemampuannya.

Dalam kegiatan bermain perlu adanya kemampuan yang dikembangkan, salah satunya kemampuan kreativitas. Loris Malaguzzi, yang merupakan salah satu pendiri pendekatan reggio emilia, percaya bahwa semua anak memiliki kemampuan kreativitas alami, dan perlu diberi kesempatan untuk menumbuhkan kemampuan ini secara maksimal. Malaguzzi memberi penekanan kuat pada cara unik untuk mengekspresikan diri mereka sendiri, yang dia sebut sebagai "100 bahasa anak-anak." Menurutnya, anak-anak menggunakan "bahasa" ini melalui berbagai cara seperti berbicara, menyanyi, melukis dan menggambar, mendramatisir, dan bermain (Thornton dan Brunton, 2010). Adapun pendekatan reggio emillia menggunakan dasar pemikiran John Dewey, Piaget, Brunner, Howard Gardner dan Vygotsky. Jika dipahami dari sudut pandang John Dewey yang mengatakan bahwa belajar berdasarkan pengalaman akan membantu anak dalam mengkonstruk pengetahuan yang melibatkan pengetahuan yang sebelumnya sudah dipelajari dengan pengetahuan yang baru diperoleh. Selain itu juga Vygotsky mengatakan bahwa anak memiliki kemampuan dalam menyelesaikan permasalahan yang tentunya melibatkan interaksi sosial di lingkungannya. Dari sini dapat dilihat bahwa bahwa pendekatan reggio emillia merupakan pendekatan yang tepat dalam mengembangkan kemampuan kreativitas pada anak. Hal ini dikarenakan 
kemampuan kreativitas pada anak akan terbentuk dengan cara anak diberikan kesempatan dalam mengeksplor lingkungan sekitar sehingga dengan cara diberikan kebebasan anak akan lebih berani dalam mengekspresikan ide-ide yang diperolehnya. Selain itu juga pendekatan reggio emillia menekankan pada lingkungan yang mendidik. Tentunya dengan adanya keterlibatan lingkungan maka akan adanya interaksi sosial didalamnya. Berdasarkan penjelasan diatas, dapat dimaknai bahwa bermain yang berbasis pendekatan reggio emillia membantu menstimulasi kreativitas pada anak usia dini.

\section{METODE}

Metode yang digunakan adalah studi kepustakaan. Menurut Nazir (2003: 111), "Studi kepustakaan adalah teknik pengumpulan data dengan mengadakan studi penelaahan terhadap buku-buku, literatur-literatur, catatan-catatan, dan laporan- laporan yang ada hubungannya dengan masalah yang dipecahkan". Adapun sumber- sumber kepustakaan yang digunakan dalam penelitian ini yaitu jurnal, buku, dan hasil dari penelitian. Penelitian ini dilakukan dengan tahapan yaitu mengidentifikasi teori- teori secara sistematis, mengkaji teori dan topik penelitian yang dibahas, menganalisis teori-teori yang berhubungan dengan topik penelitian serta memberikan kesimpulan dari hasil analisis untuk memberikan informasi yang berhubungan dengan topik penelitian.

\section{HASIL}

Berdasarkan hasil analisis terhadap kajian teori dapat dijelaskan bahwa bermain berbasis pendekatan reggio emillia dapat membantu menstimulasi kreativitas anak usai dini. Hal ini didukung dengan hasil penelitian (Gencer \& Gonen, 2015) menunjukkan bahwa kegiatan yang dilakukan dengan pendekatan reggio emillia memiliki efek pada keterampilan berfikir kreatif anak-anak. Berfikir kreatif disini dipahami dengan pola pikir yang menunjukkan kedewasaan dalam menentukan pilihan untuk menyelesaikan permasalahan yang dihadapi dalam kehidupan. Permasalahan pada anak usia dini tentunya tidak dapat disamakan dengan permasalahan orang dewasa. Adapun permasalahan yang sering dihadapi oleh anak usia dini sifatnya sederhana misalnya terkendala dalam menjawab pertanyaan sesuai dengan yang diajukan guru terkait materi pelajaran, terkendala dalam menciptakan gagasan berdasarkan pengalaman, terkendala dalam mengenal kemungkinan alternatif, terkendala dalam keberanian untuk mencoba hal-hal yang baru, terkendala dalam percaya diri mengemukakan pendapat, dan lain-lain. Anak dikatakan memiliki kreativitas yang baik apabila anak memiliki kemampuan dalam menentukan kemungkinan alternatif dalam suatu permasalahan, anak percaya diri dalam mengemukakan ide-ide atau gagasan yang diperolehnya dari hasil kegiatan eksplorasi lingkungan di sekitarnya, dan anak akan memiliki keberanian dalam mencoba hal-hal yang baru yang sebelumnya tidak pernah dilakukan.

\section{PEMBAHASAN}

\section{A. Kreativitas}

Santrock (2007: 342) menyatakan bahwa kreativitas merupakan kemampuan dalam berfikir merumuskan ide-ide baru dan menggabungkannya dengan ide-ide lama kemudian mengkombinasikannya sehingga terbentuknya sebuah pemahaman. Dalam hal ini kemampuan berfikir tersebut digunakan dalam menyelesaikan permasalahan- permasalahan yang dihadapi seseorang di lingkungan sekitarnya. Perlu dipahami bahwa kreativitas orang yang satu dengan yang lainnya tidak dapat disamakan, hal ini bergantung dari sudut pandang masing-masing individu. 
Menurut Isbell \& Raines (2007: 3), "Kreativitas telah digambarkan sebagai "berpikir di luar kotak", beberapa percaya bahwa kreativitas adalah pemikiran yang fleksibel, sedangkan yang lain melihatnya sebagai jenis pemecahan masalah khusus". Ada yang mengatakan kreativitas melakukan banyak hal dengan cara yang unik, yang lain percaya bahwa kreativitas mengharuskan orang untuk keluar dari pola kesamaan. Kreativitas telah digambarkan sebagai produksi pemikiran, solusi, dan / atau produk baru berdasarkan pengalaman dan pengetahuan sebelumnya (Hendrick, 1986). Kreativitas memungkinkan anak untuk menciptakan sesuatu yang baru dan mengkombinasikan ide yang sudah ada dengan ide yang baru. Hal ini sejalan dengan tujuan utama dalam seni kreatif menurut Eliason \& Jenkins (2008: 375) yaitu mengkomunikasikan ide. Mitchell (2004) menyatakan bahwa kreativitas adalah kemampuan untuk menciptakan atau membuat sesuatu yang baru, menggunakan keterampilan sendiri tanpa menggunakan pola atau model tertentu. Kreativitas ini berkembang ketika anak-anak setiap hari berpartisipasi dalam kegiatan yang melibatkan gerakan, permainan dramatis, dan seni visual.

Yuliani (2010: 38) menyatakan bahwa kreativitas adalah kemampuan seseorang dalam melakukan perubahan setiap saatnya yang tentunya perubahan tersebut bertujuan untuk menciptakan kebahagiaan. Dalam melakukan perubahan tentunya diperlukan keberanian atau dikenal dengan percaya diri. Kreativitas ditandai dengan memiliki sikap percaya diri yang tinggi. Anak yang memiliki kreativitas yang tinggi tentunya akan memiliki sikap percaya diri yang tinggi. Selain itu, anak yang memiliki kreativitas akan ditunjukkan dengan sikap berani mengambil keputusan, sikap percaya diri dalam menunjukkan pilihan alternatif yang diyakininya. Dari penjelasan diatas, dapat disimpulkan bahwa kreativitas ialah kemampuan seseorang dalam berfikir untuk mengkombinasikan ide-ide lama dengan ide-ide baru sehingga menciptakan suatu pemahaman yang baru

\section{B. Bermain}

Bermain merupakan salah satu kebutuhan yang mutlak yang wajib diperoleh anak usia dini. Bermain dapat menyalurkan energi yang dimiliki anak terlihat dari anak tidak akan pernah diam dalam waktu lama, selalu bergerak disetiap kesempatan, selalu tertarik akan hal-hal baru yang belum pernah dilihatnya. Plato adalah salah satu filsuf yang memandang bahwa bermain memiliki nilai. Begitu juga dengan Aristoteles yang menjelaskan bahwa pentingnya anak-anak diberikan kesempatan bermain yang nantinya akan membentuk sikap pada saat anak tumbuh dewasa. Hurlock (1997: 320) bermain merupakan kegiatan yang dilakukan dengan tujuan untuk memperoleh kesenangan yang tentunya tanpa mempertimbangkan hasil akhir. Dalam hal ini dapat dipahami bahwa kegiatan bermain memiliki tujuan yang jelas dan sesuai dengan kebutuhan anak usia dini. Bermain itu menyenangkan, dilakukan dengan senang hati melakukannya, bebas dari aturan yang dipaksakan dari luar, spontan, dan sukarela (Kostelnik, Soderman, \& Whiren (2007: 380). Kegiatan bermain dilakukan tanpa adanya paksaan dan membutuhkan keterlibatan aktif dari pemain. Menurut Yuliani (2010: 19) kegiatan bermain dapat mengoptimalkan dimensi perkembangan anak usia dini dengan lingkungan disekitarnya. Dimensi perkembangan anak usia dini meliputi sikap pengetahuan, kreativitas, keterampilan dan lain-lain. Kegiatan bermain yang baik tentunya tidak dapat melepaskan dimensi perkembangan anak usia dini. Dimensi perkembangan anak yang berkembang dengan baik akan membentuk sikap yang berorientasi pada sisi yang positif. Terlihat dari penjelasan diatas, dapat ditarik kesimpulan bahwa bermain merupakan sebuah kebutuhan mutlak yang perlu diperoleh anak. 


\section{Bermain Berbasis Pendekatan Reggio Emillia}

Bermain ialah kebutuhan yang sangat berpengaruh dalam kehidupan anak. Perlu diketahui bagi anak usia dini bermain merupakan bagian dari belajar. Proses belajar anak dilakukan sambil bermain sehingga sudah sepatutnya kegiatan bermain akan membantu anak dalam mengembangkan pengetahuan. Anak yang hanya belajar tanpa bermain tentunya akan menyebabkan kebosanan sehingga anak tidak akan menyerap materi pelajaran dengan baik. Anak perlu dilibatkan secara aktif dalam mengkonstruk pengetahuan. Anak yang bermain secara aktif akan membantu dirinya dalam mengembangkan kreativitas. Hal ini didukung dengan hasil penelitian (Oncu \& Unluer, 2010) menunjukkan bahwa bermain adalah salah satu komponen penting dalam kehidupan anak dan ini merupakan salah satu kegiatan yang dapat mengembangkan imajinasi dan kreativitas anak.

Kostelnik, Soderman, \& Whiren (2007: 26-27) menyatakan bahwa metode yang digunakan dalam pendekatan reggio emilia bersifat fleksibel dan memungkinkan input dan pengambilan keputusan ada di anak dan guru. Metodenya harus disesuaikan dengan setiap konteks dan situasi, serangkaian masalah, dan sumber daya. Asas yang paling penting pada pendekatan reggio emilia adalah pengajaran harus didasarkan pada pengamatan yang cermat terhadap anak-anak. Guru mulai dengan secara aktif mengumpulkan ide dan pemikiran anak-anak, mempertimbangkan pengetahuan, pertanyaan, dan preferensi apa yang dimiliki anak-anak sebelum merumuskan rencana dan proyek. Berangkat dari sebuah pemahaman mengenai bermain berbasis pendekatan reggio emillia dapat dijelaskan bahwa kegiatan bermain ini lebih menekankan pada kebebasan anak yang terarah untuk mengeksplorasi lingkungan di sekitarnya. Lingkungan yang dibutuhkan dalam bermain berbasis pendekatan reggio emillia adalah lingkungan yang mendidik anak. Lingkungan yang mendidik disini lebih memprioritaskan pada suasana yang mendukung kebutuhan anak. Bermain berbasis pendekatan reggio emillia menggabungkan beberapa komponen sehingga menjadi satu kesatuan yang terpadu. Pandangan yang dapat dipahami dari bermain berbasis pedekatan reggio emillia tidak jauh berbeda dengan penerapan pendekatan reggio emillia. Pendekatan reggio emillia dalam proses pembelajaran menekankan keaktifan anak dalam menganalisis temuan-temuan dari permasalahan yang diperoleh.

Dari sini dapat dijelaskan bahwa bermain berbasis pendekatan reggio emillia memberikan kesempatan pada anak dalam mengekspresikan ide-ide yang diperoleh dari lingkungan disekitarnya. Adapun keberanian dalam mengekspresikan ide-ide dan selanjutnya ide-ide tersebut direspon dengan baik oleh guru akan memberikan kontribusi sebuah keyakinan pada anak bahwa dirinya perlu melakukan eksplorasi tersebut secara berulang-ulang. Hal ini merupakan bagian dari seseorang tersebut memiliki kreativitas. Hal ini sejalan dengan hasil penelitian (Bayanova, 2014) menunjukkan bahwa kreativitas pada akan berkembang dengan baik jika anak diberikan kebebasan dalam mengeksplor lingkungannya tanpa adanya batasan-batasan yang dapat menghalangi anak dalam memunculkan ideide atau gagasan.

Bermain berbasis pendekatan reggio emillia memiliki kontrol atas apa yang dilakukan oleh anak. Selain itu juga bermain berbasis pendekatan reggio emillia juga menciptakan kondisi yang akan mendorong anak untuk berinteraksi dengan lingkungan disekitarnya. Kreativitas tidak akan terbentuk dengan sendirinya namun juga perlu adanya komunikasi dengan orang-orang disekitarnya. Komunikasi juga salah satu cara yang dapat digunakan untuk memunculkan ide-ide atau gagasan. Hal ini sejalan dengan hasil penelitian (Popescu, M.I., Moraru, A., Sava, N.I, 2015) menunjukkan bahwa perkembangan yang harmonis pada anak didukung dengan lingkungan yang dapat menstimulasi dengan tepat. Perkembangan disini 
merujuk pada perkembangan kemampuan kreativitas yang perlu ditingkatkan salah satunya. Pendekatan reggio emillia memperhatikan komponen-komponen tersebut dan menyediakannya agar dapat dirasakan oleh anak secara langsung. Hal ini didukung dengan hasil penelitian (Zahra, Yusooff, \& Hasimb, 2013) menunjukkan bahwa kreativitas anak dapat ditingkatkan dengan adanya pendidikan dan pelatihan. Pendidikan yang baik ialah pendidikan yang menyediakan kebutuhan bagi siswanya dalam melakukan kegiatan belajar. Baik itu dari ketersediaan lingkungan yang mendukung, sumber daya manusianya yang profesional, perangkat kurikulum yang tepat sesuai dengan sasaran, model pembelajaran yang diterapkan dalam kegiatan belajar.

\section{SIMPULAN}

Berdasarkan pembahasan diatas dapat disimpulkan bahwa sudah sewajarnya bermain adalah kebutuhan yang perlu didapatkan oleh anak. Belajar melalui bermain akan memberikan pengkondisian yang berbeda jika dibandingkan dengan belajar tanpa bermain. Bermain tidak hanya sekedar bermain saja namun bermain yang diperlukan oleh anak usia dini adalah bermain yang dapat menyediakan kebutuhannya dalam mengembangkan dirinya. Pengembangan diri disini dapat berupa kemampuan, salah satunya kemampuan kreativitas. Kreativitas saat ini menjadi sebuah kemampuan prioritas yang perlu ditingkatkan guna menghadapi percepatan laju globalisasi. Bermain berbasis pendekatan reggio emillia merupakan cara yang dapat digunakan untuk membantu menstimulasi kreativitas pada anak usia dini.

\section{DAFTAR PUSTAKA}

Bayanova, L. (2014). Compliance with Cultural Rules of Children Having Different Level of Creativity. Procedia - Social and Behavioral Sciences. 146. 192-195. Diperoleh 17 Maret 2018, dari http://eresources.pnri.go.id.

Eliason, C., Jenkins, L. (2008). A Practical Guide to Early Childhood Curriculum. Columbus, Ohio: Merril Prentice Hall.

Gencer, A. A., Gonen, M. (2015). Reggio Emilia Based Projects on Preschool Children's Creative Thinking Skills. Procedia - Social and Behavioral Sciences. 186 (312). 456-460. Diperoleh 16 Maret 2018, dari http://eresources.pnri.go.id.

Hendrick, J. (1986). Total Learning: Curriculum for The Young Child. Colombus, OH: Merrill.

Hurlock, Elizabeth B. (1978). Perkembangan Anak Jilid I. (Alih bahasa: dr. Med Meitasari Tjandrasa dan Muchlichah Zarkasih). Jakarta: Erlangga.

Isbell, Rebbeca T., Rainess, Shirley C. (2007). Creativity and the Arts with Young Children Second edition. USA: DELMAR CENGAGE Learning.

Kostelnik, Marjorie J., Soderman, Anne K.., Whiren, Alice P. (2007). Developmentally Appropriate Curriculum Best Practice in Early Childhood Education Fourth Edition. New Jersey: PEARSON Merrill Prentice Hall.

Nazir, M. (2003). Metode Penelitian. Jakarta: Ghalia Indonesia.

Oncu, E. C., Unluer, E. (2010). Preschool children's using of play materials creatively.

Procedia - Social and Behavioral Sciences. 2 (2). 4457-4461. Diperoleh 17 Maret 2018, dari http://eresources.pnri.go.id.

Popescu, M.I., Moraru, A., Sava, N.I. (2015). Familial Barriers in the Development of Creativity in Preschoolers. Procedia - Social and Behavioral Sciences. 187. 601-606. Diperoleh 16 Maret 2018, dari http://eresources.pnri.go.id. 
Santrock, J. W. (2007). Perkembangan Anak Jilid 1 Edisi: Kesebelas. Jakarta: Erlangga.

Sujiono, Yuliani Nurani. (2010). Bermain Berbasis Kreatif Berbasis Kecerdasan Jamak. Jakarta: Indeks.

Zahra, P., Yusooff, F., Hasim, M.S. (2013). Effectiveness of Training Creativity on Preschool Students. Procedia - Social and Behavioral Sciences. 102. 643-647. Diperoleh 17 Maret 2018, dari http://eresources.pnri.go.id. 